\title{
The Role of Acid Sites in the Catalytic Performance of Tungsten Oxide during the Dehydration of Isopropyl and Methyl Alcohols
}

\author{
Abd El-Aziz A. Said*, Mohamed M. M. Abd El-Wahab, Mohamed Abd El-Aal \\ Chemistry Department, Faculty of Science, Assiut University, Egypt
}

Copyright $\subset 2016$ by authors, all rights reserved. Authors agree that this article remains permanently open access under the terms of the Creative Commons Attribution License 4.0 International License

\begin{abstract}
WO}_{3}$ catalyst was prepared by thermal decomposition of ammonium metatungstate (AMT) in a static air atmosphere for $3 \mathrm{~h}$ at $450,550,650$ and $750^{\circ} \mathrm{C}$. The techniques employed for characterization of the catalyst were TG, DTA, XRD, FTIR, $\mathrm{N}_{2}$-sorption measurements. The surface acidity of the catalyst was investigated by adsorption of pyridine and 2, 6-dimethyl pyridine. The catalytic properties of the catalyst were carried out for the dehydration of isopropyl and methyl alcohols. The results revealed that $\mathrm{WO}_{3}$ is more active toward isopropanol dehydration than methanol dehydration. Also reflect that the reaction mechanism and the yield of propene and dimethyl ether produced from dehydration of isopropyl and methyl alcohols are controlled by the strength of acid sites.
\end{abstract}

Keywords $\mathrm{WO}_{3}$, Isopropanol, Methanol, Dehydration, Acidity

\section{Introduction}

Tungsten oxide is a solid of acidic character with many applications in heterogeneous catalysis [1]. It can be used as catalysts [2, 3], gas sensors [4], and chromogenic materials [5]. The industrial preparation of tungsten oxide is mostly based on thermal decomposition (oxidation or reduction) of ammonium tungstates.

It has been reported that bulk $\mathrm{WO}_{3}$ is an active catalyst for hydrocracking, dehydrogenation, isomerization, reforming, alcohol dehydration, and Olefin oligomerization reactions, but high temperature was required because of its low surface area and weak acid sites [6, 7]. Recently, Balzer et al. [8] found that $\mathrm{WO}_{3}$ catalyst exhibited high catalytic activity in the oxidation of benzene, toluene, and xylenes (BTX). They found that the benzene conversion exceeded $70 \%$ and the tolueneconversion exceeded $50 \%$ at $350^{\circ} \mathrm{C}$. They also stated that the performance of the $\mathrm{WO}_{3}$ catalyst may be due to the number of exposed active sites and greater oxygen mobility.

Dehydration of alcohols is very interesting process, commonly used for studying the acid character of the catalyst surfaces. The activity and selectivity of this reaction are controlled by texture, acidity and electronic properties of the catalyst [9].The conversion of isopropyl alcohol has been related to the presence of both acid and basic sites on the surface of the catalysts. In the broad outline, isopropyl alcohol dehydrates to propene over acid catalysts and dehydrogenates to acetone over basic catalysts $[10,11]$.

Kulkarni et al. [12] observed that $\mathrm{WO}_{3}$ yielded acidic products in the range of $170-200^{\circ} \mathrm{C}$, it produced significant quantities of isopropyl ether along with propene when using flow a mixture of oxygen and helium. A series of $\mathrm{WO}_{\mathrm{x}} / \mathrm{Al}_{2} \mathrm{O}_{3}$ catalysts was investigated in 2-propanol dehydration in the temperature range of $130-140^{\circ} \mathrm{C}$ by Chen et al. [13]. They found that, the $\gamma-\mathrm{Al}_{2} \mathrm{O}_{3}$ support was inactive, while, the $\mathrm{WO}_{\mathrm{x}} / \mathrm{Al}_{2} \mathrm{O}_{3}$ catalysts exhibited activity toward propene and diisopropyel ether and the selectivity of propene was higher than $80 \%$. However, Martín et al. [14] found that isopropanol adsorbs dissociatively on $\mathrm{WO}_{3} / \mathrm{Nb}_{2} \mathrm{O}_{5}$ and $\mathrm{WO}_{3} / \mathrm{Al}_{2} \mathrm{O}_{3}$ supports, leading to acetone and propene formation on tugsta-niobia, but only propene on tungsta-alumina. Pae et al. [15] have tested the catalytic activities of $10-\mathrm{NiO}-\mathrm{TiO}_{2} / \mathrm{WO}_{3}$ catalysts for 2-propanol dehydration. They observed that the dehydration ability increased by increasing $\mathrm{WO}_{3}$ content up to 25 wt. $\%$.

On the other hand, it was reported that supported $\mathrm{WO}_{\mathrm{x}}$ catalysts are less active in methanol dehydration than conventional zeolite-type-catalysts [16] they do not present strong acid sites, which could result in an extended life time of the catalyst. Furthermore, the presence of water would not impact negatively on the catalytic performance. A series of model-supported $\mathrm{WO}_{3}$ catalysts were synthesized by Kim et al. [17] on performed $\mathrm{Al}_{2} \mathrm{O}_{3}, \mathrm{Nb}_{2} \mathrm{O}_{5}, \mathrm{TiO}_{2}$, and $\mathrm{ZrO}_{2}$ supports and chemically probed with methanol dehydration to dimethyl ether. They found that the specific support significantly affects the relative catalytic acidity of the surface $\mathrm{WO}_{\mathrm{x}}$ species $\left(\mathrm{Al}_{2} \mathrm{O}_{3}>>\mathrm{TiO}_{2}>\mathrm{Nb}_{2} \mathrm{O}_{5}>\mathrm{ZrO}_{2}\right)$ to that of the supported $\mathrm{WO}_{3}$ nano particles. It was reported that the catalytic results of methanol oxidation reaction over $\mathrm{WO}_{\mathrm{x}} / \mathrm{Al}_{2} \mathrm{O}_{3}, \mathrm{WO}_{\mathrm{x}} / \mathrm{Nb}_{2} \mathrm{O}_{5}$ and $\mathrm{WO}_{\mathrm{x}} / \mathrm{ZrO}_{2}$ catalysts is mainly 
dimethyl ether, and formaldehyde over $\mathrm{WO}_{\mathrm{x}} / \mathrm{CeO}_{2}$ [18]. Also, the $\mathrm{WO}_{\mathrm{x}} / \mathrm{CeO}_{2}$ catalysts possess high redox reactivity and the $\mathrm{WO}_{\mathrm{x}} / \mathrm{Al}_{2} \mathrm{O}_{3}$ catalyst possesses the highest acid reactivity. Recently, Behera et al. [19] noted that 25 wt. \% $\mathrm{WO}_{3}-\mathrm{VPO}$ catalyst exhibited good activity for the selective gas phase oxidation of methanol with $>90 \%$ conversion at around $250^{\circ} \mathrm{C}$ by using total flow rate of $60 \mathrm{~mL} \mathrm{m^{-1 }}$ ( $\mathrm{MeOH}: \mathrm{O}_{2}: \mathrm{He}=5: 10: 85$ ). According to the above literature survey, we noted that the pure $\mathrm{WO}_{3}$ catalyst has not received as much attention.

However, comparing the catalytic performance of pure $\mathrm{WO}_{3}$ in dehydration of both isopropanol and methanol, to our knowledge, has not yet been reported. Therefore, the present work was devoted to study the role of active acid sites on pure $\mathrm{WO}_{3}$ towards the dehydration of isopropanol and methanol with emphasis given to the effects of physicochemical characteristics of catalysts on catalytic performance.

\section{Materials and Methods}

\subsection{Materials and Catalyst Preparation}

Ammonium metatungestate hydrate $\left(\mathrm{NH}_{4}\right)_{6} \cdot \mathrm{H}_{2} \mathrm{~W}_{12} \mathrm{O}_{40} \cdot \mathrm{xH}$ ${ }_{2} \mathrm{O}$ (AMT) (Fluka Analytical), isopropyl alcohol (IPA), methyl alcohol (MA), pyridine (PY) and 2, 6-dimethyl pyridine (DMPY) were obtained as pure reagents and were used without further purification. $\mathrm{WO}_{3}$ catalyst was prepared by direct thermal decomposition of AMT in a static air atmosphere for $3 \mathrm{~h}$ at $450,550,650$ and $750^{\circ} \mathrm{C}$.

\subsection{Catalyst Characterization}

\subsubsection{Thermal Analysis}

The TGA and DTA measurements of AMT were performed in air $\left(30 \mathrm{~mL} \mathrm{~min}^{-1}\right)$ by a Shimadzu thermal analyzer; model (TGA- $60 \mathrm{H})$, and the heating rate was $10^{\circ} \mathrm{C}$ per minute using $10-15 \mathrm{mg}$ of the sample.

\subsubsection{X-ray Diffraction (XRD)}

XRD powder diffraction patterns of the samples was conducted on a Philips (The Netherlands) diffractometer (Model PW 2103) using $\mathrm{Ni}$-filtered $\mathrm{CuK} \alpha$ radiation with a voltage and current of $40 \mathrm{kV}$ and $20 \mathrm{~mA}$, respectively. Patterns were recorded from 4 to $80^{\circ}(2 \theta)$. The crystal sizes of different phases in the sample were determined from the full width at half maximum (FWHM) of the peaks using Scherrer equation [20]

$$
D=\frac{\mathrm{K} \lambda}{\boldsymbol{\beta} \operatorname{Cos} \theta}
$$

Where $\mathrm{K}$ is a dimensionless shape factor, with a value close to unity, $\mathrm{D}$ is the mean crystallite diameter $(\mathrm{nm}), \lambda$ is the $\mathrm{X}$-ray wavelength $(0.15418 \mathrm{~nm}), \theta$ is the Bragg angle, and $\boldsymbol{\beta}$ is the FWHM in radians after correction.

\subsubsection{Fourier Transform Infrared (FT-IR) Spectroscopy}

FT-IR spectra of AMT calcined at 450,550, 650 and $750^{\circ} \mathrm{C}$ for $3 \mathrm{~h}$ were recorded at room temperature in the $400-4000 \mathrm{~cm}^{-1}$ range with a Nicolet 6700 Series FTIR spectrometer using disks of samples diluted in $\mathrm{KBr}$.

\subsubsection{Nitrogen Gas Adsorption}

The specific surface area, pore volume and average pore diameter were measured on a Nova 3200 instrument (Quantachrom Instrument Corporation, USA) using $\mathrm{N}_{2}$ as analytic gas. Test samples were degassed at $250^{\circ} \mathrm{C}$ for $3 \mathrm{~h}$ prior to the analysis. The specific surface area, $\mathrm{S}_{\mathrm{BET}}$ was calculated by the conventional BET method. The pore volume was calculated from the amount of vapor adsorbed at a relative pressure $\left(P / P^{0}\right)$ close to unity. Pore size distribution was obtained using $\mathrm{BJH}$ model and the desorption branch.

\subsubsection{Catalytic Activity Measurements}

The catalytic activity of the catalysts under investigation for the vapor - phase dehydration of IPA and MA were carried out in the temperature range of $100-275^{\circ} \mathrm{C}$ in a conventional fixed bed flow type reactor at atmospheric pressure using nitrogen as a carrier gas. The system was previously described [21]. The total flow rate was fixed at 50 $\mathrm{mL} \min ^{-1}$ and used $2 \%$ and $4 \%$ reactants of IPA and MA respectively in the gas feed and $500 \mathrm{mg}$ catalyst weight. The gases after reaction were chromatographically analyzed by FID with a Unicam ProGC using a $10 \%$ PEG $(2 \mathrm{~m})$ and a $2 \mathrm{~m}$ DNP column for analysis of the reaction products of IPA and MA respectively on the tested catalysts. Measurements of the conversion and yield (\%) were recorded after $1 \mathrm{~h}$ from the initial introduction of the reactants into the reactor.

\subsubsection{Acidity Determination}

The acidity of the catalysts under investigation was determined by studying the adsorption of PY and DMPY during the dehydration of isopropyl alcohol (IPA). The chemisorptions of PY and DMPY were carried out by injection of different volumes at steady state of IPA condition. The reaction conditions were: A $500 \mathrm{mg}$ catalyst, $2 \%$ reactant of IPA in the gas feed, $50 \mathrm{~mL} \mathrm{~min}^{-1}$ total flow rate and $180^{\circ} \mathrm{C}$ reaction temperature. The exit feed was analyzed by direct sampling of the gaseous products into a Unicam ProGC gas chromatograph using a flame ionization detector (FID) with a 10\% PEG 400 column (2 m).

\section{Results and Discussion}

\subsection{Thermal Analysis}

The TG and DTA curves for AMT are shown in Fig. 1. The TG curve indicates that the material suffers $\mathrm{Ca} .8 .6 \%$ loss of its original weight in four steps. The first step is in the range of $\left(28-135^{\circ} \mathrm{C}\right)$ with a weight loss of about $1.9 \%$ (theoretical value 1.8\%) ascribed to the loss of three 
crystalline water molecules. This step is accompanied with an endothermic peak in DTA curve minimized at $117^{\circ} \mathrm{C}$. The second step is in the range of $\left(136-200^{\circ} \mathrm{C}\right)$ with a weight loss of about $0.7 \%$ (theoretical value $0.6 \%$ ) attributed to the evolved of only one crystalline water molecule. This step is associated with the small endothermic peak in the DTA profile minimized at $146^{\circ} \mathrm{C}$. The third step is in the range of $\left(250-390^{\circ} \mathrm{C}\right)$ with a weight loss of about $4.3 \%$ (theoretical value $4.3 \%$ ) which is related to releasing five molecules of $\mathrm{NH}_{3}$ and three water molecules. This step is accompanied by an endothermic peak minimized at $321^{\circ} \mathrm{C}$ and an exothermic peak maximized at $389^{\circ} \mathrm{C}$ in the DTA profile. The fourth step is in the range of $\left(391-500^{\circ} \mathrm{C}\right)$ with a weight loss of about $1.2 \%$ (theoretical value $1.2 \%$ ) ascribed to the loss of $\mathrm{NH}_{3}$ and $\mathrm{H}_{2} \mathrm{O}$ molecules. This step has a sharp exothermic peak maximized at $444^{\circ} \mathrm{C}$. These results are in a good agreement with that obtained by Hunyadi et al. [22]. From the above results, the thermal decomposition of ammonium metatungstate can be proceeded according to the following suggested equations.

$$
\begin{array}{ll}
\left(\mathrm{NH}_{4}\right)_{6} \mathrm{H}_{2} \mathrm{~W}_{12} \mathrm{O}_{40} \cdot 4 \mathrm{H}_{2} \mathrm{O} \stackrel{28-135^{\circ} \mathrm{C}}{\longrightarrow}\left(\mathrm{NH}_{4}\right)_{6} \mathrm{H}_{2} \mathrm{~W}_{12} \mathrm{O}_{40} \cdot \mathrm{H}_{2} \mathrm{O}+3 \mathrm{H}_{2} \mathrm{O} \\
\left(\mathrm{NH}_{4}\right)_{6} \mathrm{H}_{2} \mathrm{~W}_{12} \mathrm{O}_{40} \cdot \mathrm{H}_{2} \mathrm{O} \stackrel{136-200^{\circ} \mathrm{C}}{\longrightarrow}\left(\mathrm{NH}_{4}\right)_{6} \mathrm{H}_{2} \mathrm{~W}_{12} \mathrm{O}_{40}+\mathrm{H}_{2} \mathrm{O} \\
\left(\mathrm{NH}_{4}\right)_{6} \mathrm{H}_{2} \mathrm{~W}_{12} \mathrm{O}_{40} \stackrel{250-390^{\circ} \mathrm{C}}{\longrightarrow} \mathrm{NH}_{4} \mathrm{HW}_{12} \mathrm{O}_{37}+5 \mathrm{NH}_{3}+3 \mathrm{H}_{2} \mathrm{O} \\
\mathrm{NH}_{4} \mathrm{HW}_{12} \mathrm{O}_{37} \stackrel{391-500^{\circ} \mathrm{C}}{\longrightarrow} 12 \mathrm{WO}_{3}+\mathrm{NH}_{3}+\mathrm{H}_{2} \mathrm{O}
\end{array}
$$

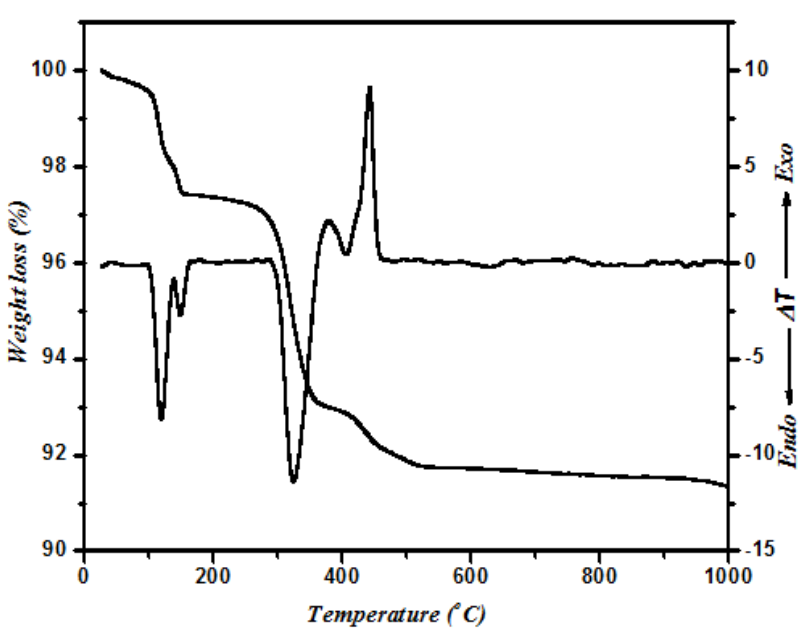

Figure 1. TG and DTA of ammonium metatungestate

\subsection{X-ray Diffraction (XRD)}

XRD diffractograms of $\mathrm{WO}_{3}$ catalyst precalcined at 450 , 550,650 and $750^{\circ} \mathrm{C}$ were determined and are illustrated in Fig. 2. The $\mathrm{WO}_{3}$ calcined at $450^{\circ} \mathrm{C}$ exhibits two most intense diffraction peaks located at $2 \theta$ angles of $23.1^{\circ}$ and $23.5^{\circ}$, which were identified with JCPDS number of 04-008-7115 (Space group P21/n) for monoclinic phase. Moreover, another two intense diffraction peak could be observed at $2 \theta$ angles of $24.2^{\circ}$ and $33.7^{\circ}$, which were identified with JCPDS number of 04-004-2790 (Space group P4/nmmz) for tetragonal phase. So, the $\mathrm{WO}_{3}$ powder prepared by this method showed a mixture of two phases of tetragonal and monoclinic. By increasing the calcination temperature up to $750^{\circ} \mathrm{C}$ the intensity of all peaks slightly increases and the samples showed a mixture of monoclinic and tetragonal phases as the same to calcine at $450^{\circ} \mathrm{C}$. The FWHM of the diffraction peaks at $2 \theta$ values of $23.2^{\circ}, 23.5^{\circ}$ and $24.2^{\circ}, 33.7^{\circ}$ were used in the Scherrer equation [20], to calculate the crystallite sizes of the monoclinic and tetragonal phases respectively. The average of these measurements was used as a crystallite sizes for the two phases. The crystallite sizes for $\mathrm{WO}_{3}$ precalcined at different temperatures are cited in Table 1 . The results obtained revealed that the crystalline sizes of the two phases of $\mathrm{WO}_{3}$ increase by increasing the calcination temperature.

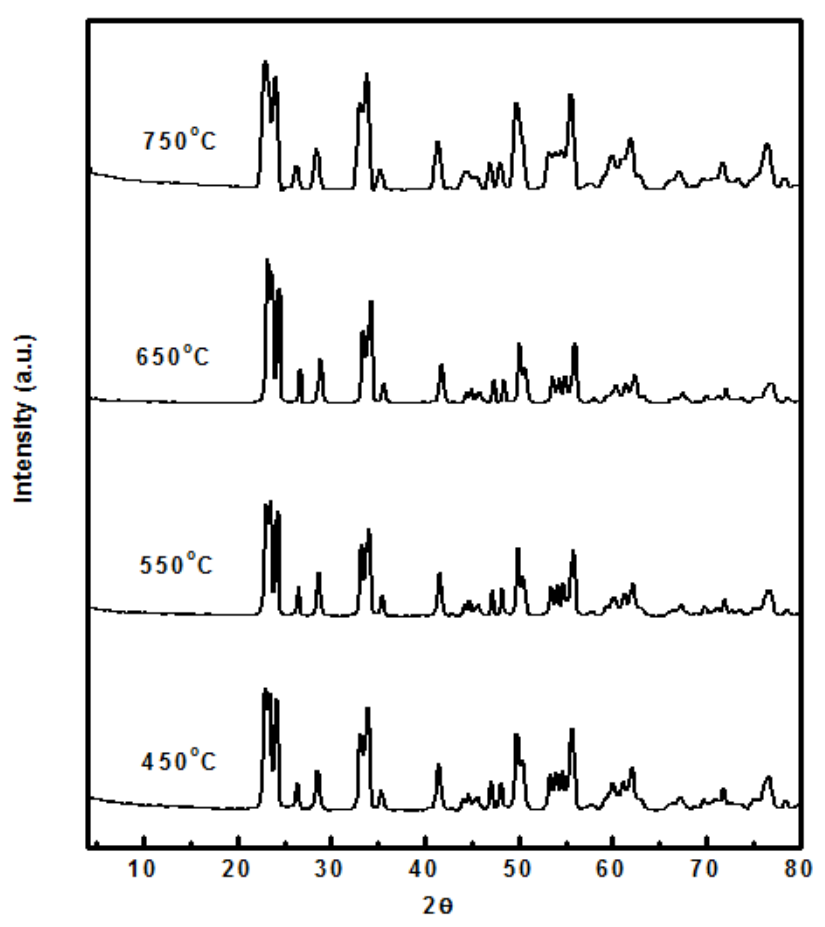

Figure 2. X-ray diffraction patterns of $\mathrm{WO}_{3}$ calcined at different temperatures.

\subsection{Fourier Transform Infrared (FTIR) Spectroscopy}

Fig. 3 shows the FTIR spectra obtained for $\mathrm{WO}_{3}$ calcined at $450,550,650$ and $750^{\circ} \mathrm{C}$ for $3 \mathrm{~h}$. The FTIR spectrum of $\mathrm{WO}_{3}$ calcined at $450^{\circ} \mathrm{C}$ shows a strong stretching band at about $814 \mathrm{~cm}^{-1}$ corresponding to W-O-W [23], and band located at $1630 \mathrm{~cm}^{-1}$ is attributed to in-plane bending vibration $\delta(\mathrm{W}-\mathrm{OH})$. Furthermore, the band located at 1438 $\mathrm{cm}^{-1}$ is associated to $\mathrm{O}-\mathrm{H}$ stretching vibration [24]. It can also be observed that, the symmetric stretching vibrations, related to $\mathrm{WO}_{3}$ and intercalated water molecules are characterized by a prominent band at $\approx 3424 \mathrm{~cm}^{-1}$. Crowder et al. [25] stated that the calcination at and above $350^{\circ} \mathrm{C}$ results in the transformation of hydrated tungsten oxide to monoclinic $\mathrm{WO}_{3}$. So, the FTIR spectra show low concentration of water. On the other hand, on increasing the 
calcination temperature up to $750^{\circ} \mathrm{C}$ there is no apparent change in the position and the intensities of all bands.

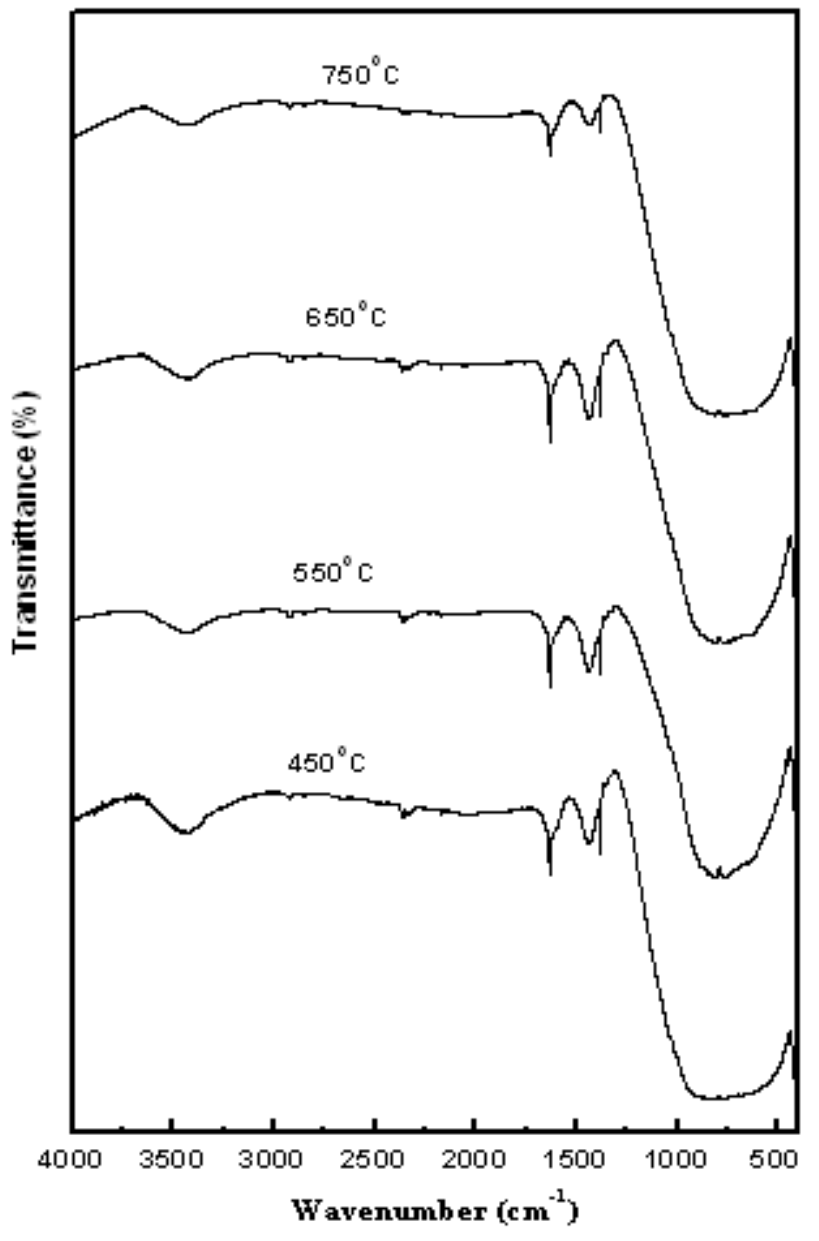

Figure 3. FTIR spectra of $\mathrm{WO}_{3}$ calcined at different temperatures.

\subsection{Surface Area Measurements}

Fig. 4 presents the $\mathrm{N}_{2}$ adsorption-desorption isotherms, $\mathrm{V}_{\mathrm{a}}-\mathrm{t}$ plots and pore size distributions of $\mathrm{WO}_{3}$ calcined at 450 , 550,650 and $750^{\circ} \mathrm{C}$. All the isotherms are attributed to type II, which is characteristic of microporous materials with hysteresis loops of the type $\mathrm{H} 4$ with little of type $\mathrm{E}$ of de Bore classification [26, 27]. The porous structure of the $\mathrm{WO}_{3}$ was also identified by $\mathrm{V}_{\mathrm{a}}$-t plots and pore size distribution for $\mathrm{WO}_{3}$ calcined at different temperatures Figs. 4(b\& c) respectively. Fig. 4b reflects that the catalysts show downward deviation which retaining the microporous texture. Moreover, the pore size distribution of $\mathrm{WO}_{3}$ (Fig. 4c) exhibits one sharp peak maximized at the value of $\mathrm{r}_{\mathrm{p}}^{-}$equal about $1.9 \mathrm{~nm}$. This behavior also indicates that the samples contain micropore structure. The specific surface areas $\mathrm{S}_{\mathrm{BET}}$, $\mathrm{S}_{\mathrm{t}}$ and texture properties of $\mathrm{WO}_{3}$ calcined at different temperatures are presented in Table 1. The $\mathrm{S}_{\mathrm{BET}}$ values of $\mathrm{WO}_{3}$ computed from linear plots of the $\mathrm{S}_{\mathrm{BET}}$ equation revealed an observable decrease in the surface area of $\mathrm{WO}_{3}$ from $\left(7.2 \mathrm{~m}^{2} / \mathrm{g}\right)$ to $\left(1.9 \mathrm{~m}^{2} / \mathrm{g}\right)$ upon increasing the calcination temperature from 450 to $750^{\circ} \mathrm{C}$. This behavior may be attributed to the sintering process. Meanwhile, the total pore volume decreased and the average pore diameter increased. It can also observed that the surface area calculated from BET and t-plots method $\left(\mathrm{S}_{\mathrm{t}}\right)$ are very closed which indicates the correct choice of the reference t-curves for analysis and shows the absence of ultra micropores [28].

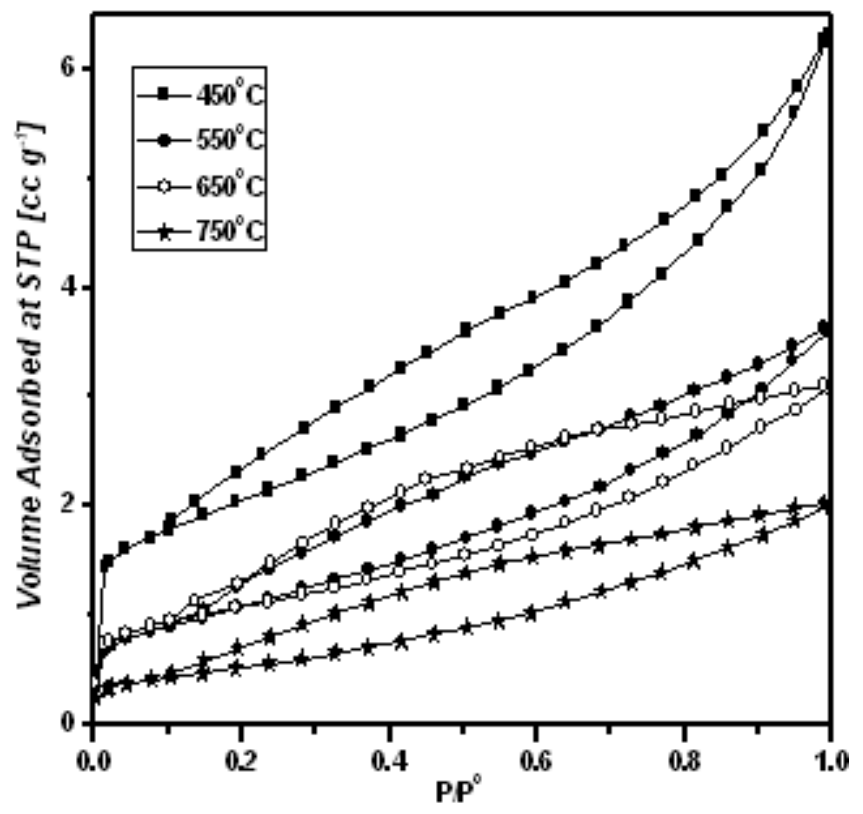

Figure 4a. Adsorption-desorption isotherms of $\mathrm{WO}_{3}$ calcined at different temperatures for $3 \mathrm{~h}$.

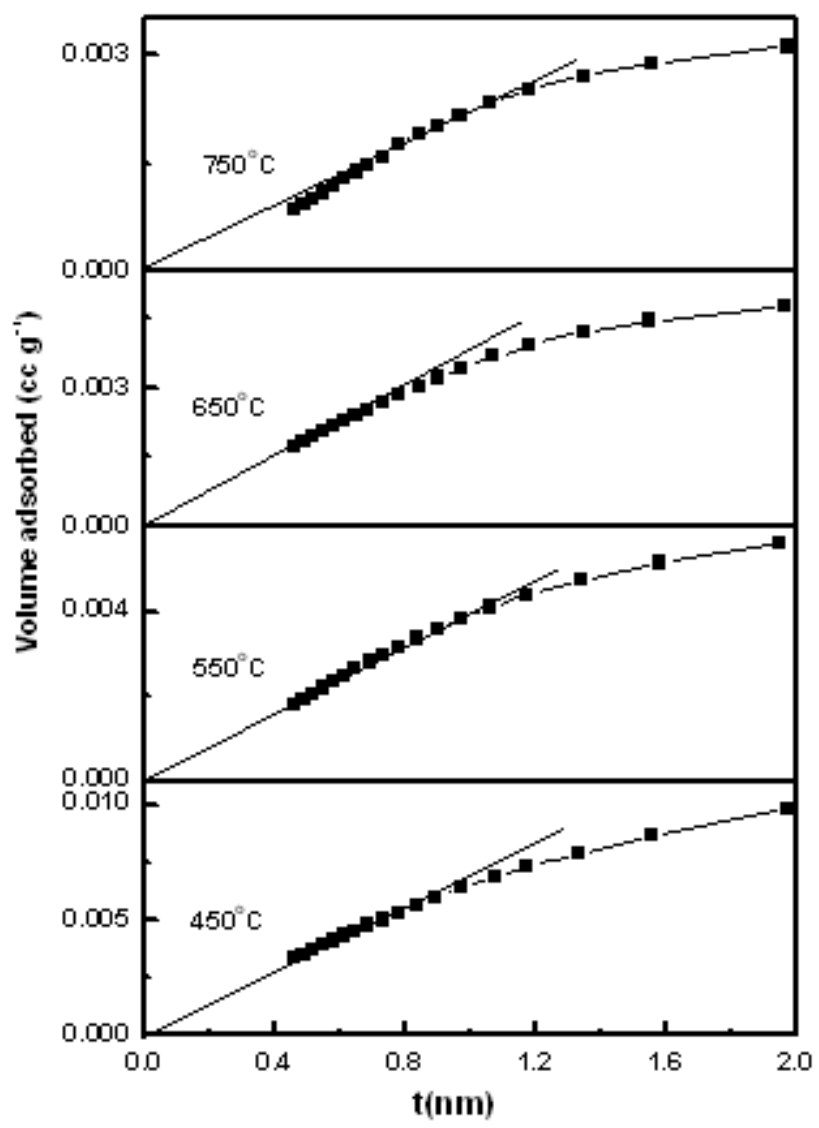

Figure 4b. $\mathrm{V}_{\mathrm{a}}$-t plots of $\mathrm{WO}_{3}$ calcined at different temperatures for $3 \mathrm{~h}$. 


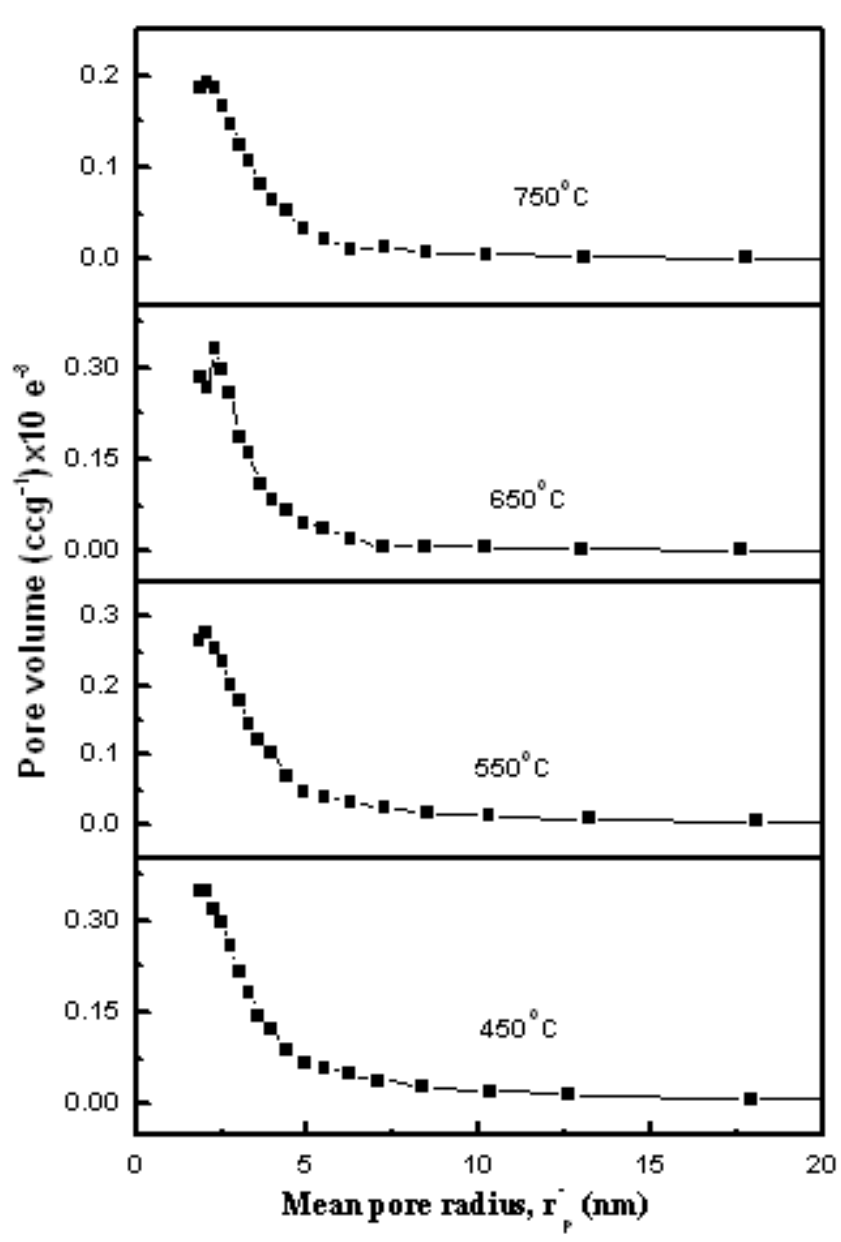

Figure 4c. Pore size distribution of $\mathrm{WO}_{3}$ calcined at different temperatures for $3 \mathrm{~h}$.

\subsection{Catalytic Activity}

\subsubsection{Conversion of Isopropyl Alcohol (IPA)}

Catalytic conversion of IPA occurs by two parallel reactions, the dehydration carried out in acidic sites giving the olefin (propene) and diisopropyel ether (DIPE) and the dehydrogenation to acetone occurring either on basic sites/ concerted acid-base pair or redox sites [29, 30]. The effect of reaction temperature on the catalytic dehydration of IPA over pure $\mathrm{WO}_{3}$ calcined at $450^{\circ} \mathrm{C}$ was carried out in the temperature range of $100-275^{\circ} \mathrm{C}$. The experimental results are shown in Fig. 5a. The results reflect that, the IPA dehydration reaction starts at $125^{\circ} \mathrm{C}$ and propene is the only product at all temperature runs. It can also observe that the yield of propene increases monotonically with increasing the reaction temperature up to $200^{\circ} \mathrm{C}$ (Maximum yield $\approx 100 \%$ ), then the steady state of yield was observed on increasing the reaction temperature up to $275^{\circ} \mathrm{C}$. On the other hand, Fig. $5 \mathrm{~b}$ shows the obtained results (conversion and selectivity) on $\mathrm{WO}_{3}$ calcined at $450,550,650$ and $750^{\circ} \mathrm{C}$ at $180^{\circ} \mathrm{C}$. In the working conditions used, $\mathrm{WO}_{3}$ calcined at $450^{\circ} \mathrm{C}$ exhibits conversion and yield of propene $\approx 94 \%$. Moreover, on increasing the calcination temperature up to $750^{\circ} \mathrm{C}$ a decrease in the conversion and the yield of propene were noticed. This behavior may be attributed to the decrease in the $\mathrm{S}_{\mathrm{BET}}$ of $\mathrm{WO}_{3}$ on calcined up to $750^{\circ} \mathrm{C}$ Table 1 . From the above results one can observe that $\mathrm{WO}_{3}$ is a catalyst with acidic character.

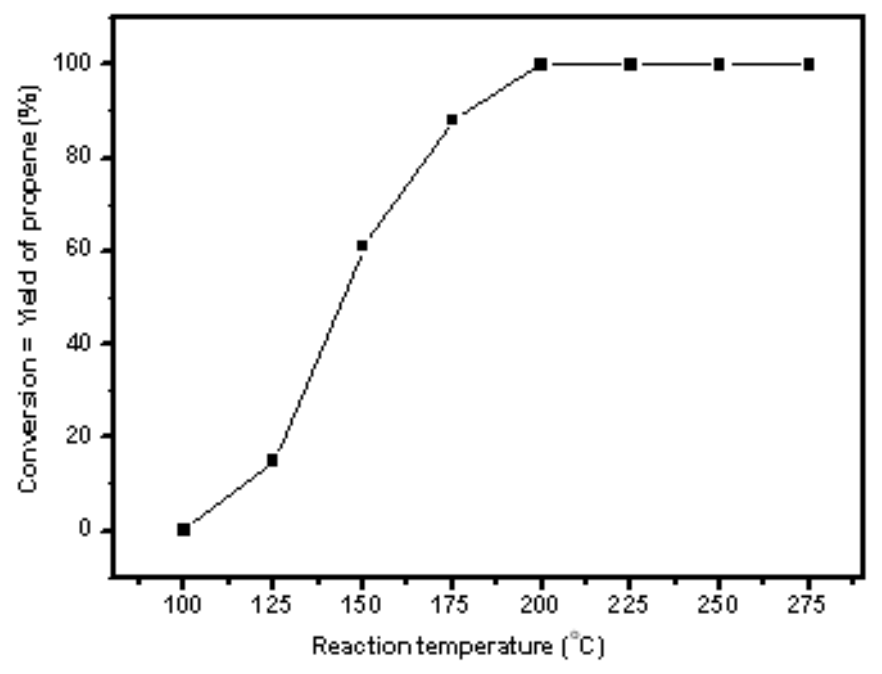

Figure 5a. Effect of reaction temperature on the dehydration of IPA over $\mathrm{WO}_{3}$ catalyst calcined at $450^{\circ} \mathrm{C}$.

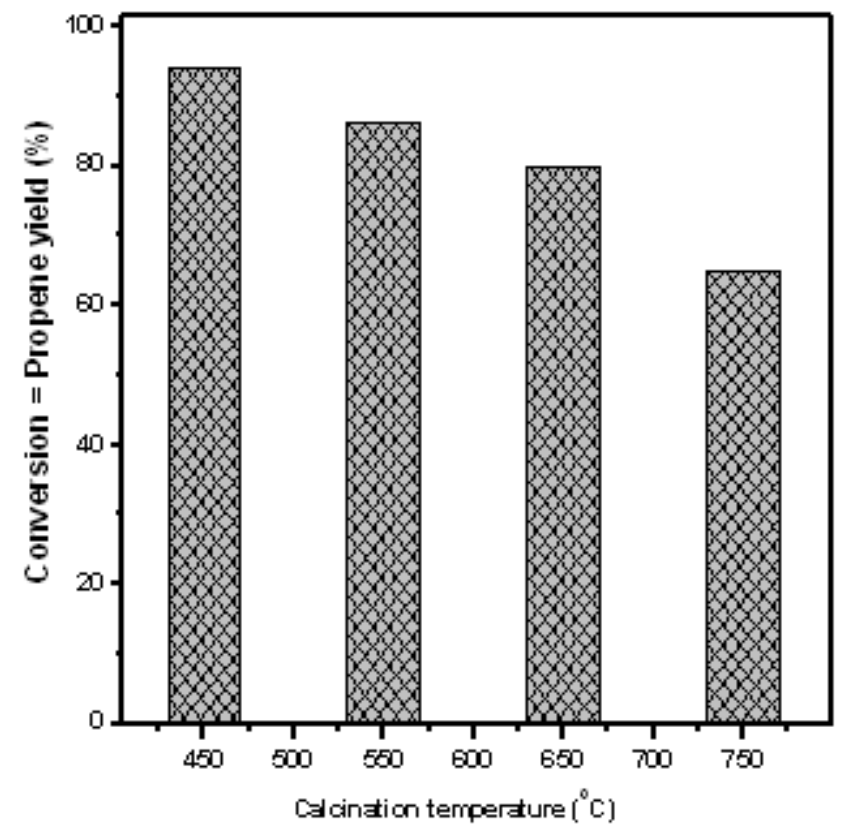

Figure 5b. Activity Variation of IPA over $\mathrm{WO}_{3}$ calcined at different temperatures for $3 \mathrm{~h}$ at $180^{\circ} \mathrm{C}$ reaction temperature. 
Table 1. Variation of specific surface area, pore characteristics and crystalline sizes of $\mathrm{WO}_{3}$ with the calcination temperatures

\begin{tabular}{|c|c|c|c|c|c|c|c|}
\hline $\begin{array}{c}\text { Calcination } \\
\text { temperature } \\
\left({ }^{\circ} \mathrm{C}\right)\end{array}$ & $\begin{array}{c}\mathrm{S}_{\mathrm{BET}} \\
\left(\mathrm{m}^{2} \mathrm{~g}^{-1}\right)\end{array}$ & $\begin{array}{c}\mathrm{S}_{\mathrm{t}} \\
\left(\mathrm{m}^{2} \mathrm{~g}^{-1}\right)\end{array}$ & $\mathrm{C}_{\mathrm{BET}}$ & $\begin{array}{c}\text { Total pore volume } \\
\left(\mathrm{cc} \mathrm{g}^{-1}\right)\end{array}$ & $\begin{array}{c}\text { Average pore } \\
\text { diameter } \\
(\mathrm{nm})\end{array}$ & $\begin{array}{c}\mathrm{D}_{\text {XRD }} \\
(\mathrm{nm})^{\mathrm{a}} \\
\text { Monoclinic }\end{array}$ & $\begin{array}{c}\mathrm{D}_{\text {XRD }} \\
(\mathrm{nm})^{\mathrm{a}} \\
\text { Tetragonal }\end{array}$ \\
\hline 450 & 7.2 & 7.2 & 300 & 0.0097 & 5.4 & 13.8 & 16.4 \\
\hline 550 & 3.9 & 3.9 & 300 & 0.0056 & 5.7 & 14.5 & 24.8 \\
\hline 650 & 3.7 & 3.7 & 128 & 0.0048 & 5.1 & 16.8 & 25.0 \\
\hline 750 & 1.9 & 1.9 & 113 & 0.0031 & 6.4 & 17.0 & 25.6 \\
\hline
\end{tabular}

${ }^{a}$ Crystalline size : determined by XRD results.

\subsubsection{Dehydration of Methanol to DME}

Previous reports have addressed the role of Brønsted and Lewis acid sites on MA dehydration reactions [31, 32]. It was reported that the Brønsted acidity might exhibit higher activity than Lewis acidity for the dehydration of MA, since water is a product of MA dehydration; the presence of water decreased the strength of Lewis acidity [33].

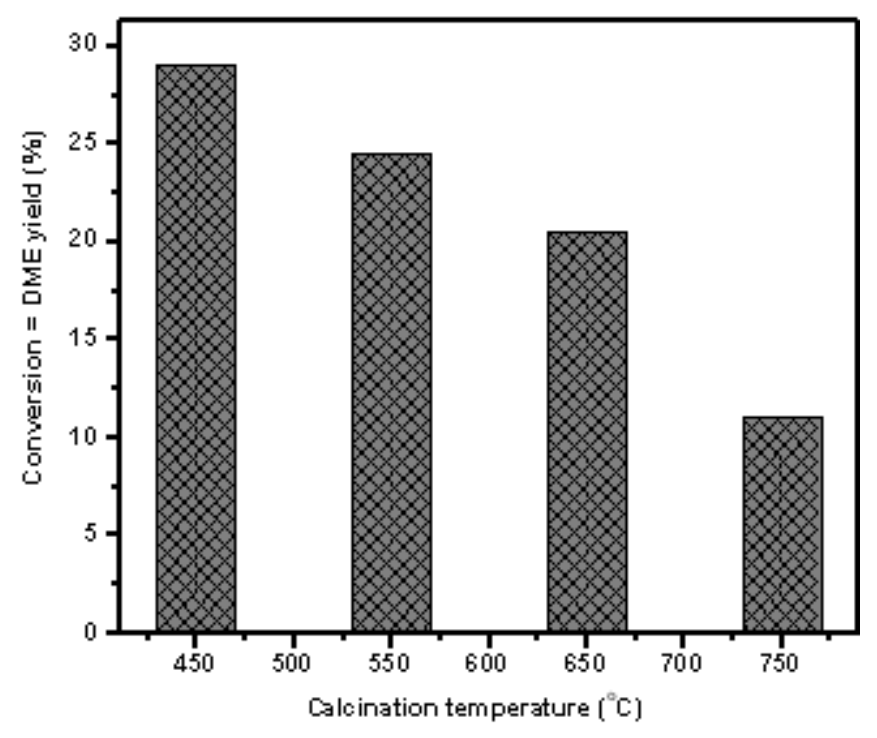

Figure 6a. Activity variation of $\mathrm{MA}$ over $\mathrm{WO}_{3}$ catalyst calcined at different temperatures for $3 \mathrm{~h}$ at $230^{\circ} \mathrm{C}$ reaction temperature.

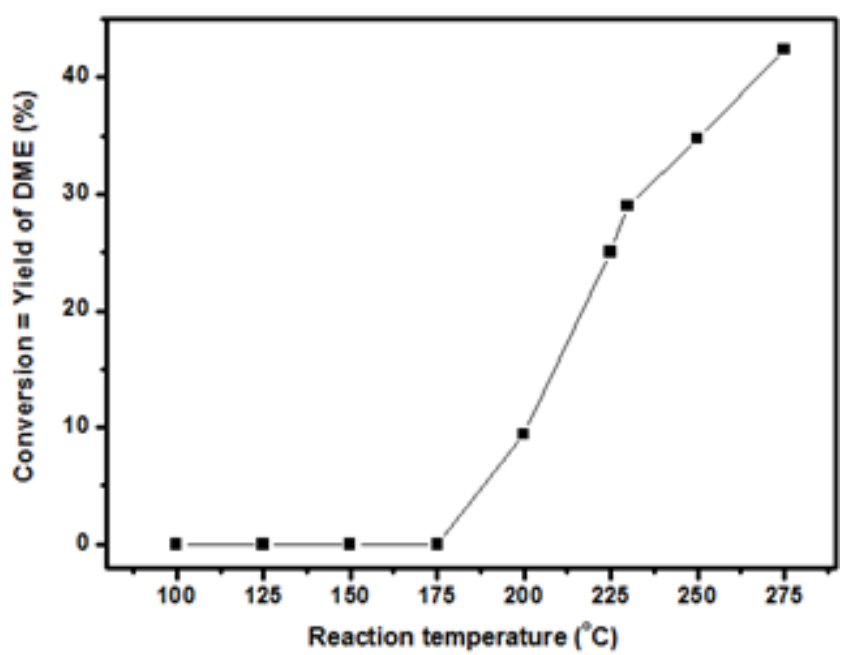

Figure 6b. Effect of reaction temperature on the dehydration of MA over $\mathrm{WO}_{3}$ catalyst calcined at $450^{\circ} \mathrm{C}$.
The MA dehydration was carried out at relatively low temperature $230^{\circ} \mathrm{C}$ to evaluate the catalytic performance of tungsten oxide. Fig. 6a displayed the results of MA catalytic dehydration on $\mathrm{WO}_{3}$ catalyst calcined at $450,550,650$, $750^{\circ} \mathrm{C}$ for $3 \mathrm{~h}$. The results revealed that $\mathrm{WO}_{3}$ calcined at $450^{\circ} \mathrm{C}$ exhibits $\approx 29 \%$ conversion of methanol and $100 \%$ selectivity to DME. On increasing the calcination temperature up to $750^{\circ} \mathrm{C}$ the MA conversion drastically decreases and reaches to $\approx 11 \%$, while the selectivity toward DME formation still $100 \%$. The observed decrease in MA conversion may be attributed to the decrease in the surface area, Table 1.

The effect of reaction temperature on the catalytic dehydration of methanol over pure $\mathrm{WO}_{3}$ calcined at $450^{\circ} \mathrm{C}$ was carried out and the results are represented in Fig. $6 \mathrm{~b}$. From this figure one can observe that the reaction starts at $200^{\circ} \mathrm{C}$ and the methanol conversion and the yield of DME steadily increase with increasing the reaction temperature up to $275^{\circ} \mathrm{C}$ (Maximum yield $\approx 42.4 \%$ ). Furthermore, on increasing the reaction temperature above $275^{\circ} \mathrm{C}$, no noticeable change in the methanol conversion, but the selectivity to DME decreases because formaldehyde as a side reaction was observed.

\subsection{Determination of the Surface Acidic Sites}

\subsubsection{Poisoning of $\mathrm{WO}_{3}$ Catalyst Acid Sites with Pyridine} and 2, 6-dimethyl Pyridine during the Dehydration of IPA

Chemisorption of small basic molecules such as PY and DMPY is often used to probe the acidity of solids. These molecules interact with acidic sites because they have a lone electron pair at the nitrogen atom available for donation to Lewis (L) acidic site and because they can accept a proton from Brønsted (B) sites [34]. It was demonstrated that PY is adsorbed on both (B) and (L) acid sites and DMPY sensitive for probing (B) acid sites [35, 36]. So, the difference between PY and DMPY adsorption is a measure of the (L) acid sites. The poisoning of the active surface sites of $\mathrm{WO}_{3}$ catalyst calcined at $450^{\circ} \mathrm{C}$ in IPA conversion was performed through saturation of the acid sites with PY and DMPY according to the procedure described previously [26]. The results obtained are shown in Fig 7. It shows that the chemisorbed PY and DMPY decrease the yield of propene by $68 \%$ and $62 \%$, respectively, and the difference between the amounts adsorbed is $\approx 6 \%$. This value corresponds to the $(\mathrm{L})$ acid sites 
and this confirms that, the $\mathrm{WO}_{3}$ is an acidic catalyst with major (B) and minor (L) acid sites.

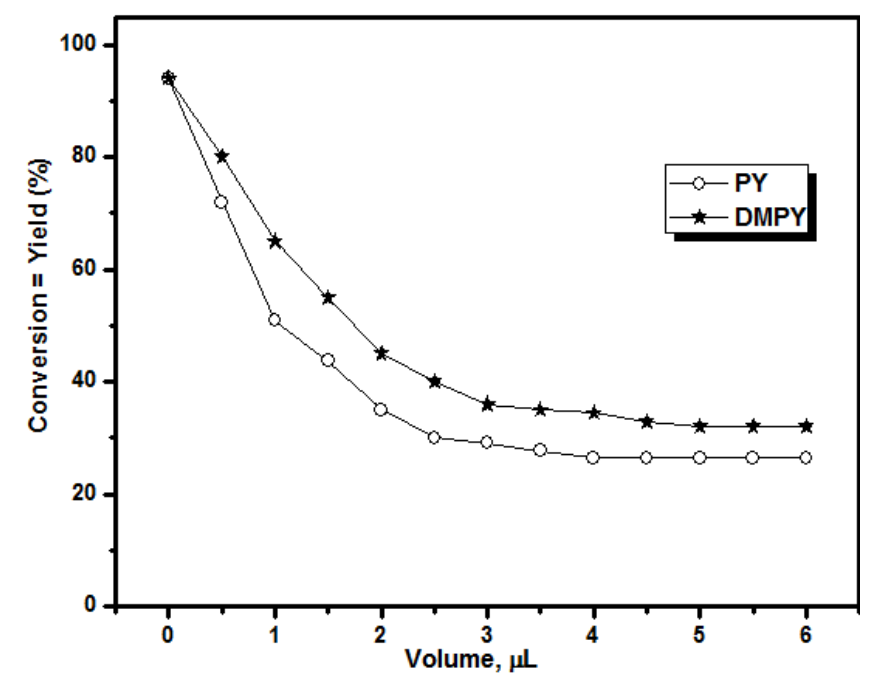

Figure 7. Activity variation of IPA with the volume of PY and DMPY over $\mathrm{WO}_{3}$ calcined at $450^{\circ} \mathrm{C}$ for $3 \mathrm{~h}$ at $180^{\circ} \mathrm{C}$ reaction temperature.

3.6.2. The Effect of the Catalytic Reaction Temperature on the Dehydration of IPA $\mathrm{WO}_{3}$ Catalyst Presaturated with PY and DMPY

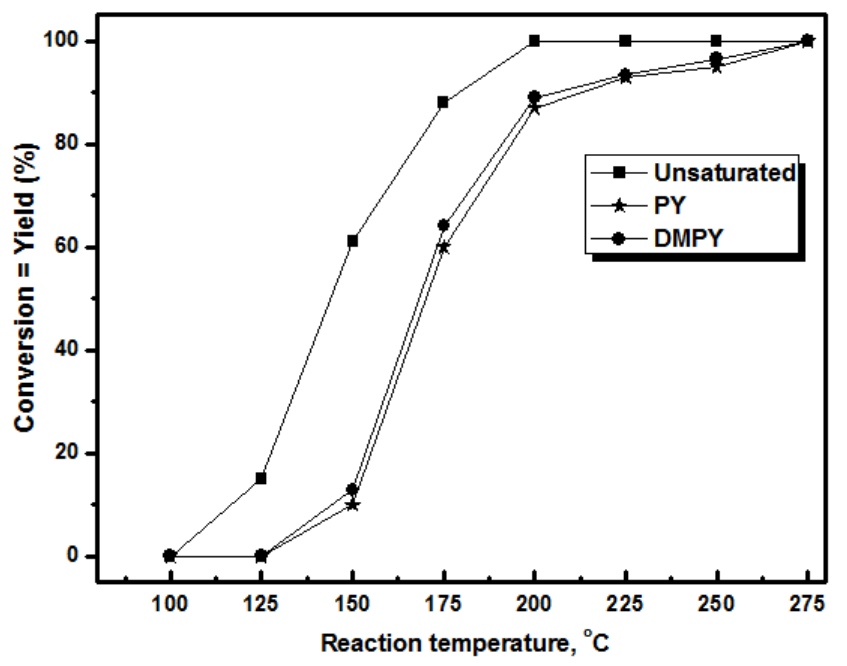

Figure 8. Activity variation of IPA with reaction temperature over presaturated $\mathrm{WO}_{3}$ catalyst with PY and DMPY.

It is known that Brønsted and Lewis acid sites are capable of retaining pyridine at certain temperatures. The poisoning of the active acidic sites of $\mathrm{WO}_{3}$ catalyst under investigation was performed through the previous saturation of the acidic sites with PY and DMPY for 7 days after evacuation to ensure completes the saturation process. The saturated catalyst was subjected to the catalytic reaction of IPA under different reaction temperatures using similar conditions of the catalytic run as mentioned above. The effect of reaction temperature on the activity of unsaturated and saturated $\mathrm{WO}_{3}$ catalyst with PY and DMPY was carried out. The experimental results are shown in Fig. 8.The results revealed that the saturation of $\mathrm{WO}_{3}$ with both PY and DMPY retards its catalytic activity to higher temperature. By increasing the reaction temperature, the catalyst restores its original catalytic activity at $275^{\circ} \mathrm{C}$. So, the obtained results indicate that $\mathrm{WO}_{3}$ catalyst possesses only weak and intermediate acid sites. Moreover, the little difference between the activity of $\mathrm{WO}_{3}$ saturated with PY and DMPY confirms the presence of (B) major acid sites as observed in Fig. 7.

\subsection{Mechanism of IPA and MA Dehydration Reactions}

It should be noted that there is a significant difference in the activity of $\mathrm{WO}_{3}$ towards dehydration of both IPA and MA. The $\mathrm{WO}_{3}$ catalyst is more active in IPA dehydration than MA dehydration. This behavior may be attributed to the different mechanisms of the two reactants. The mechanism of acid-catalysed dehydration of IPA is suggested to occur through E1 or E2 elimination pathways [37]; the E2 pathway (bimolecular elimination) involves concerted cleavage of $\mathrm{C}-\mathrm{O}$ and $\mathrm{C}-\mathrm{H}$ bonds in alcohol using a pair of acid and base catalyst sites. The E1 pathway (monomolecular elimination) breaks the $\mathrm{C}-\mathrm{O}$ bond in alcohol in the rate-limiting step using an acid site to form water and carbenium ion; the latter undergoes proton abstraction to form alkenes. As the $\mathrm{WO}_{3}$ catalyst is an acidic catalyst with major (B) and minor (L) acid sites Fig. 5, IPA is firstly adsorbed onto (B) or (L) acid sites followed by the scission of hydroxyl group to form alkoxy species. In the presence of (B) acid sites, water is eliminated in this step and the alkoxy group decomposes into alkene and the proton. In the presence of (L) acid sites, the hydroxyl group cleaved in the first step and the proton generated is combined again and desorbed as water. On the other hand, Carr et al. [38] considered that MA dehydration on (B) acid sites proceeded by sequential and direct routes. The sequential route involves sequential reactions of MA through methoxide intermediates [39], and a concerted reaction between two adsorbed methanol molecules occurred. In the direct dehydration routes, MA monomers form, but the second MA adsorbs and interacts to form protonated dimmers before water elimination forms methoxides. These dimmers then rearrange to co-adsorbed species with the atomic orientation to form DME and $\mathrm{H}_{2} \mathrm{O}$ in a single, subsequent step. According to the above two mechanisms of IPA and MA dehydration, in IPA dehydration one molecule should be adsorbed to form propene. While, in MA dehydration two molecules should be adsorbed and reacted to form DME. However, it was reported that the catalyst with a large number of acid sites of intermediate strength was the most favorable MA dehydration [40]. Meanwhile, IPA dehydration proceeds quickly on weak acid sites [41]. So, we suggest that the IPA dehydration reaction is easier to proceed than MA dehydration reaction and consequently this explained the high activity of $\mathrm{WO}_{3}$ in IPA dehydration than in MA dehydration.

\subsection{Conclusion}

$\mathrm{WO}_{3}$ was prepared by thermal decomposition of AMT and 
characterized by XRD, FTIR and $\mathrm{N}_{2}$ sorption. The results reflected that the $\mathrm{WO}_{3}$ formed contains a mixture of tetragonal and monoclinic phases and microporous in nature. Moreover, the acidity test results indicate that the $\mathrm{WO}_{3}$ is an acidic catalyst with major (B) and minor (L) acid sites and possesses only weak and intermediate acid sites. The $\mathrm{WO}_{3}$ was tested for IPA and MA dehydration. The results revealed that $\mathrm{WO}_{3}$ is more active toward IPA dehydration than MA dehydration. This behavior is explained on the basis of the pathway of the two alcohols mechanism and the strength of the acid sites present on $\mathrm{WO}_{3}$.

\section{REFERENCES}

[1] A. F. Pérez-Cadenas, C. Moreno-Castilla, F. J. Maldonado-Hódar, J. L. G. Fierro. Tungsten oxide catalysts supported on activated carbons: effect of tungsten precursor and pretreatment on dispersion, distribution, and surface acidity of catalysts. J. Catal. 217 (2003) 30-37.

[2] C. Di Valentin, F. Wang, G. Pacchioni. Tungsten Oxide in Catalysis and Photocatalysis: Hints from DFT. Topics Catal. 56 (2013) 1404-1419.

[3] E. Karacsonyi, L. Baia, A. Dombi, V. Danciu, K. Mogyorosi, L. C. Pop, G. Kovacs, V. Cosoveanu, A. Vulpoi, S. Simon, Z. Pap. The photocatalytic activity of $\mathrm{TiO}_{2} / \mathrm{WO}_{3} /$ noble metal $(\mathrm{Au}$ or $\mathrm{Pt}$ ) nanoarchitectures obtained by selective photodeposition. Catal. Today. 208 (2013) 19-27.

[4] Y. D. Zhang, W. W. He, H. X. Zhao, P. J. Li. Template-free to fabricate highly sensitive and selective acetone gas sensor based on $\mathrm{WO}_{3}$ microspheres. Vacuum. 95 (2013) 30-34.

[5] M. Chromčíkovà, M. Liška, M. Lissovà, P. Mošner, L. Koudelka. Structural relaxation of $\mathrm{PbO}-\mathrm{WO}_{3}-\mathrm{P}_{2} \mathrm{O}_{5}$ glasses. J. Therm. Anal. Calorim. 114 (2013) 947-954.

[6] D. G. Barton, S. L. Soled, E. Iglesia. Solid acid catalysts based on supported tungsten oxides. Topics Catal. 6 (1998) 87-99.

[7] C. H. Kline, V. Kollonitsch. CATALYTIC ACTIVITY OF TUNGSTEN. II. Ind. Eng. Chem. 57 (1965)53-60.

[8] R. Balzer, V. Drago, W. H. Schreiner, L. F. D. Probst. Synthesis and Structure-Activity Relationship of a $\mathrm{WO}_{3}$ catalyst for Total Oxidation of BTX. J. Braz. Chem. Soc. 25 (2014) 2026-2031.

[9] T. Yashima, H. Suzuki, N. Hara. Decomposition of 2-propanol over alkali cation exchanged zeolites. J. Catal. 33 (1974) 486-492.

[10] M. A. Aramendia, V. Borau, C. Jiménez, J. M. Marinas, A. Porras, F. J. Urbano. Magnesium Oxides as Basic Catalysts for Organic Processes: Study of the Dehydrogenation-Dehy dration of 2-Propanol. J. Catal. 161(1996) 829-838.

[11] J. Bedia, J. M. Rosas, J. Maírquez, J. Rodríguez-Mirasol, T. Cordero. Preparation and characterization of carbon based acid catalysts for the dehydration of 2-propanol. Carbon 47(2009) 286-294.
[12] D. Kulkarni, I. E.Wachs. Isopropanol oxidation by pure metal oxide catalysts: number of active surface sites and turnover frequencies. Appl. Catal. A: Gen. 237(2002) 121-137.

[13] X. Chen, G. Clet, K. Thomas, M. Houalla. Correlation between structure, acidity and catalytic performance of $\mathrm{WO}_{\mathrm{x}} / \mathrm{Al}_{2} \mathrm{O}_{3}$ catalysts. J. Catal. 273 (2010) 236-244.

[14] C. Martín, G. Solana, P. Malet, V. Rives. $\mathrm{Nb}_{2} \mathrm{O}_{5}$-supported $\mathrm{WO}_{3}$ : a comparative study with $\mathrm{WO}_{3} / \mathrm{Al}_{2} \mathrm{O}_{3}$. Catal. Today 78 (2003) 365-376.

[15] Y. I. Pae, M. H. Bae, W. C. Park, J. R. Sohn. Characterization of $\mathrm{NiO}-\mathrm{TiO}_{2}$ Modified with $\mathrm{WO}_{3}$ and Catalytic Activity for Acid Catalysis. Bull. Korean Chem. Soc. 25(2004)1881-1888.

[16] J. J. Spivey. REVIEW: DEHYDRATION CATALYSTS FOR THE METHANOL/DIMETHYL ETHER REACTION. Chem. Eng. Commun. 110 (1991)123-142.

[17] T. Kim, A. Burrows, C. J. Kiely, I. E. Wachs. Molecular/electronic structure-surface acidity relationships of model-supported tungsten oxide catalysts. J. Catal. 246 (2007) 370-381.

[18] Y.-M. Dai, T.-C. Pan, J.-M. Jehng. Methanol Oxidation over the Nanoscale Supported Tungsten Oxide Catalysts. Adv. Mater. Res. 253-235 (2011) 1460-1463.

[19] G. C. Behera, K. Parida, N. F. Dummer, G. Whiting, N. Sahu, A. F. Carley, M. Conte, G. J. Hutchings, J. K. Bartley. Tungstate promoted vanadium phosphate catalysts for the gas phase oxidation of methanol to formaldehyde. Catal. Sci. Technol. 3 (2013) 1558-1564.

[20] A. A. Said, M. M. Abd El-Wahab, M. Abd El-Aal. Effect of $\mathrm{ZrO}_{2}$ on the catalytic performance of nano $\gamma-\mathrm{Al}_{2} \mathrm{O}_{3}$ in dehydration of methanol to dimethyl ether at relatively low temperature. Res. Chem. Intermedia. 42 (2016)1537-1556.

[21] A. A. Said, M. M. Abd El-Wahab, M. Abd El-Aal. The catalytic performance of sulfated zirconia in the dehydration of methanol to dimethyl ether. J. Mol. Catal. A: Chem. 394 (2014) 40-47.

[22] D. Hunyadi, I. Sajó, I. M. Szilágyi. Structure and thermal decomposition of ammonium metatungstate. J. Therm. Anal. Calorim. 116 (2014)329-337.

[23] V. B. Kumar, D. Mohanta. Formation of nanoscale tungsten oxide structures and colouration characteristics. Bull. Mater. Sci. 34 (2011) 435-442.

[24] H. Habazaki, Y. Hayashi, H. Konno. Characterization of electrodeposited $\mathrm{WO}_{3}$ films and its application to electrochemical wastewater treatment. Electrochimica. Acta 47(2002) 4181-4188.

[25] B. L. Crowder, M. J. Sienko. Solid State Studies of Tungsten Trioxide Single Crystals below Room Temperature. Inorg. Chem. 4 (1965) 73-77.

[26] A. A. Said, M. M. Abd El-Wahab, M. Abd El-Aal. Catalytic dehydration of methanol to dimethyl ether over nanosized $\mathrm{WO}_{3} / \mathrm{Al}_{2} \mathrm{O}_{3}$ system under inert and oxidative atmosphere. Monatsh Chem. (2016) (Accepted manuscript).

[27] J. H. de Boer, E. P. Everette, F. S. Stone, Eds. "The structure and properties of porous materials" Butterworths, (London) 68 (1958). 
[28] N. R. E. Radwan, G. A. Fagal, G. A. El-Shobaky. Effects of $\mathrm{CeO}_{2}$-doping on surface and catalytic properties of $\mathrm{CuO} / \mathrm{Al}_{2} \mathrm{O}_{3}$ solids. Colloid Surface A. 178 (2001) 277-286.

[29] S. Y. Liu, S. M. Yang. Complete oxidation of 2-propanol over gold-based catalysts supported on metal oxides. Appl. Catal. A: Gen. 334 (2008) 92-99.

[30] R. M. Rioux, M. A. Vannice. Dehydrogenation of isopropyl alcohol on carbon-supported $\mathrm{Pt}$ and $\mathrm{Cu}-\mathrm{Pt}$ catalysts. J. Catal. 233 (2005) 147-165.

[31] K. Lertjiamratn, P. Praserthdam, M. Arai, J. Panpranot. Modification of acid properties and catalytic properties of $\mathrm{AlPO}_{4}$ by hydrothermal pretreatment for methanol dehydration to dimethyl ether. Appl. Catal. A: Gen. 378 (2010) 119-123.

[32] V. Vishwanathan, H.-S. Roh, J.-W. Kim, K.-W. Jun. Surface Properties and Catalytic Activity of $\mathrm{TiO}_{2}-\mathrm{ZrO}_{2}$ Mixed Oxides in Dehydration of Methanol to Dimethyl Ether. Catal. Lett. 96 (2004) 23-28.

[33] Y. Fu, T. Hong, J. Chen, A. Auroux, J. Shen.Surface acidity and the dehydration of methanol to dimethyl ether. Thermochimica. Acta 434 (2005) 22-26.

[34] G. Berhault, M. Lacroix, M. Breysse, F. Maugé, J.-C. Lavalley, H. Nie, L. Qu. Characterization of Acidic Sites of Silica-Supported Transition Metal Sulfides by Pyridine and 2,6 Dimethylpyridine Adsorption: Relation to Activity in $\mathrm{CH}_{3} \mathrm{SH}$ Condensation. J. Catal. 178 (1998) 555-565.

[35] A. A. Said, M. M. Abd El-Wahab, A. M. Alian. Catalytic performance of Brønsted acid sites during esterification of acetic acid with ethyl alcohol over phosphotungestic acid supported on silica. J. Chemical Technol. Biotechnol. 82 (2007) 513-523.

[36] F. M. Bautista, J. M. Campelo, A. Garcia, D. Luna, J. M. Marinas, M. C. Moreno, A. A. Romero. Acidity and catalytic activity of $\mathrm{AlPO}_{4}-\mathrm{B}_{2} \mathrm{O}_{3}$ and $\mathrm{Al}_{2} \mathrm{O}_{3}-\mathrm{B}_{2} \mathrm{O}_{3}\left(5-30 \mathrm{wt} \% \mathrm{~B}_{2} \mathrm{O}_{3}\right.$ ) systems prepared by impregnation. Appl. Catal. A: Gen. 170 (1998) 159-168.

[37] G. C. Bond, S. J. Frodsham, P. Jubb, E. F. Kozhevnikova, I. V. Kozhevnikov. Compensation effect in isopropanol dehydration over heteropoly acid catalysts at a gas-solid interface. J. Catal. 293 (2012) 158-164.

[38] R. T. Carr, M. Neurock, E. Iglesia. Catalytic consequences of acid strength in the conversion of methanol to dimethyl ether. J. Catal. 278 (2011)78-93.

[39] M. V. Luzgin, M. S. Kazantsev, W. Wang, A. Stepanov. Reactivity of Methoxy Species toward $\mathrm{CO}$ on Keggin $12-\mathrm{H}_{3} \mathrm{PW}_{12} \mathrm{O}_{40}$ : A Study with Solid State NMR. J. Phys. Chem. C 113 (2009)19639-19644.

[40] D. Mao, W. Yang, J. Xia, B. Zhang, G. Lu. The direct synthesis of dimethyl ether from syngas over hybrid catalysts with sulfate-modified $\gamma$-alumina as methanol dehydration components. J. Mol. Catal. A: Chem. 250 (2006) 138-144.

[41] T. Kakaoka, J. A. Dumesic. Acidity of unsupported and silica-supported vanadia, molybdena, and titania as studied by pyridine adsorption. J. Catal. 112 (1988) 66-79. 